\title{
Penggunaan Metode Sosiodrama dan Pengaruhnya Terhadap Peningkatan Siswa dalam Kemahiran Berbicara
}

\author{
Farhan Faizan \\ Institut Agama Islam Negeri (IAIN) Syekh Nurjati Cirebon \\ Email: Farhanfaizan28@gmail.com \\ Maman Dzuliman \\ Institut Agama Islam Negeri (IAIN) Syekh Nurjati Cirebon \\ Email: mamandzuliman@gmail.com \\ Wahyudin \\ Institut Agama Islam Negeri (IAIN) Syekh Nurjati Cirebon \\ Email: wahyudin@gmail.com
}

\begin{abstract}
Abstrak
Penelitian ini bertujuan untuk mengetahui seberapa besar pengaruh penggunaan metode sosiodrama terhadap peningkatan kemampuan keterampilan berbicara (maharah kalam) di kelas VIII MTs Alwashliyah Talun Cirebon. Serta Salah satu faktor yang mempengaruhi berhasil tidaknya suatu pembelajaran adalah guru. Oleh karena itu, guru harus pandai memilih metode yang tepat dan sesuai agar tujuan pembelajaran yang diharapkan dapat tercapai dengan maksimal. Salah satu alternative yang digunakan adalah dengan menerapkan metode sosiodrama dalam pembelajaran kemampuan berbicara (maharat kalam).Bahwasanya metode sosiodrama merupakan salah satu metode pembelajaran yang di arahkan untuk mempermudah siswa dalam memahami pembelajaran.Dan juga merupakan metode yang efektif, karena metode ini mampu memberikan pemahaman bagi siswa dan membuat mereka lebih semangat lagi dalam belajar khususnya dalam pembelajaran kemampuan keterampilan Berbicara. Penelitian ini menggunakan metode kuantitatif dengan jenis metode Quasi Eksperimental. Metode pengumpulan data dalam penelitian ini adalah dengan cara observasi,tes, dan dokumentasi sedangkan analisis data dalam penelitian ini adalah dengan menggunakan,uji normalitas, uji homogenitas uji $\mathrm{t}$ tes dan uji hipotesis. Hasil dari penelitian ini adalah bahawas terdapat pengaruh penggunaan metode sosiodrama terhadap peningkatan kemampuan siswa dalam keterampilan berbicara.
\end{abstract}

\section{Kata Kunci: Sosiodrama, Kemampuan Siswa, Keterampilan berbicara}

\section{Abstract}

The purpose of this research how much influence the use of Sosiodrama Methode to increase student Speaking Skills in learning Arabic in class VIII MTs AlWashliyah Cirebon. And One of the factors that influence the success or 
failure of learning is the teacher. Therefore, teachers must be clever in choosing the right methods so that the expected learning objectives can be achieved to the maximum. One alternative that is used is to apply Sociodrama method in Speaking learning. That picture media is one of the learning media that is directed to facilitate students in understanding learning. And Sociodrama method is an effective method, because this method able to provide understanding for students and make them even more enthusiastic in learning, especially in Speaking Skills learning. This research uses quantitative methods with the type of Quasi experimental methods. Data collection methods in this study are by observation, tests and Documentation, while data analysis in this study is to use,normality test, homogeneity test $t$ test and hypothesis test. The results of this study are that there is an influence of the use of Sociodrama method to increase ability students in the Speaking Skills.

Keywords: Sociodrma, Student Ability, Speaking Skills

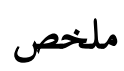

يهدف هذا البحث إلى تحديد مدى استخدام طريقة المسرحية الإجتماعيةعلى ترقية مهارة الكلام الفصل الثامن بمدرسة الوصلية المتوسطة الإسلامية شربون. وأحد العوامل التي تؤثر على نجاح أو فشل التعليم هو المعلم. لذلك ، يجب أن يكون المعلم أذكياء في اختيار الوسائل التعليمية الصحيحة والأساليب بحيث يمكن تحقيق أهداف التعليم المحصول إلى الحد الأقصى. أحد البدائل المستخدمة هو تطبيق طريقة المسرحية الإجتماعية في تعليم مهارة الكلام، وطريقة المسرحية الإجتماعيةهي طريقة فعالة ، لأن هذه الطريقة قادرة على توفير قدرة للطلاب و جعلهم أكثر نشاطا في التعليم ، وخاصة في مهارة الكلام. ومنهج البحث في هذه الرسالة هو بحث كمي بإجرءات البحث التجريبي. طريقة جمع البيانات في هذه الدراسة هي الملاحظة والاختبار والوثائق. وطريقة تحليل البيانات التي يستخدمها الباحث في هذا الرسالة هي وتجربة العادية وتجربة المتجانس وتجربة الفروض. ونتائج هذه الرسالة على أن تعليم مهارة الكلام باستخدام طريقةالمسرحية الإجتماعية فعال ويستوعبونمهارة الكلام جيدا. الكلمة الرئيسية: طريقة المسرحية الاجتماعية، قدرة الطلاب، مهارة الكلام

\section{Pendahuluan}

Dalam pembelajaran bahasa, kemampuan menggunakan bahasa disebut kemahiran berbahasa. Pada umumnya, semua pakar pembelajaran bahasa sepakat bahwa keterampilan dan kemahiran 
berbahasa Arab tersebut terbagi menjadi empat. Diantaranya adalah keterampilan menyimak, keterampilan berbicara, keterampilan membaca dan keterampilan menulis.

Dalam pemerolehan keterampilan berbahasa, kita biasanya melalui hubungan urutan yang teratur,mula-mula pada masa kecil, kita belajar menyimak/mendengarkan bahasa, kemudian berbicara, sesudah itu kita belajar membaca dan menulis. ${ }^{1}$

Keterampilan berbicara (maharah al-kalam) adalah kemampuan mengungkapkan bunyi-bunyi artikulasi atau kata-kata untuk mengekspresikan pikiran berupa ide,pendapat, keinginan, atau perasaan kedalam mitra bicara. Adapunberbicara merupakan kombinasi faktorfaktor fisik, psikologi, neurologis, semantik, dan linguistik secara luas. Sehingga, dapat dianggap sebagai alat manusia yang paling penting bagi kontrol sosial. ${ }^{2}$

Dengan demikian, untuk menunjang hal tersebut di perlukan adanya pembelajaran yang menarik, tidak monoton sehingga pembelajaran tata bahasa yang di berikan oleh guru tidak cepat di lupakan ${ }^{3}$

Dalam kegiatan belajar, tidak semua anak didik yang diajar mempunyai kemampuan untuk berkonsentrasi dalam waktu yang relatife lama. Daya tangkap antara peserta didik yang satu dengan yang lain berbeda, selain itu tingkat intelegensi setiap siswa juga berbeda. Berdasarkan beberapa factor perbedaan sebagaimana tersebut diatas, memerlukan strategi pengajaran yang tepat. Dalam hal ini Guru mempunyai peranan penting dalam suatu proses pendidikan.

Pelajaran bahasa arab merupakan pelajaran yang dianggap sulit dan dianggap sebuah momok oleh siswa. Untuk mengatasi hal tersebut maka diperlukan suatu terobosan baru dalam proses pembelajaran bahasa, sehingga siswa lebih mudah untuk memahami materi yang disampaikan dan merasa senang untuk belajar bahasa arab. Sehingga seorang Guru dituntut untuk mampu menguasai berbagai metode dan strategi dalam proses pembelajaranya. Metode merupakan bagian

${ }^{1}$ Tarigan,Menulis sebagai suatu keterampilan berbahasa. (Bandung; Angkasa, 2008). Hal. 1.

2 Lihat Tarigan, Berbicara sebagai suatu keterampilan Berbahasa., (Bandung; Angkasa,1981).

3 Lihat Trianto, Model pembelajaran terpadu dalam teori dan praktek, (Jakarta; Prestasi Pustaka, 2007) 
komponen pengajaran yang menduduki posisi penting, selain tujuan, Guru, peserta didik, media, lingkungan, dan evaluasi ${ }^{4}$ Salah satu metode yang bisa digunakan adalah metode sosiodrama. Dimana sosiodrama dapat menjadi salah satu alternative dalam menciptakan suasana belajar yang menyenangkan ${ }^{5}$

Metode sosiodrama pada dasarnya mendramatisasikan tingkah laku dalam hubungan dengan masalah social ${ }^{6}$ Sosiodrama digunakan untuk memberikan pemahaman dan penghayatan akan masalah social serta mengembangkan kemampuan siswa untuk memecahkannya Bahasa arab merupakan pelajaran mengenai bahasa yang mana didalam praktiknya tidak terlepas dari percakapan, metode sosiodrama diterapkan bertujuan agar siswa lebih mampu mengembangkan keterampilan berbahasa, disamping membantu untuk lebih memahami isi ataupun materi pelajaran. Dengan metode ini siswa akan lebih banyak melakukan kegiatan belajar, sebab siswa tidak hanya mendengarkan uraian Guru tetapi juga melakukan aktifitas lain seperti memahami, membuat dan menulis naskah drama, melakukan demonstrasi serta kegiatan lainya dalam berbahasa Arab sehingga siswa tidak merasa jenuh. ${ }^{7}$

Dalam praktiknya metode sosiodrama sering digunakan dalam pembelajaran yang banyak berkaitan dengan sosial khususnya mata pelajaran bahasa Arab, bahasa Indonesia. Metode sosiodrama tidak hanya digunakan dalam pembelajaran di kelas saja akan tetapi dapat menghasilkan suatu karya berupa naskah drama berbahasa Arab dan dapat di pertunjukan melalui teater yang mana dapat mengembangkan kreatifitas siswa dalam berkarya dan khususnya berbahasa Arab.

Hal ini dikarenakan metode sosiodrama dalam praktiknya secara tidak langsung mampu mencakup kemahiran-kemahiran yang harus dicapai dalam suatu pembelajaran bahasa Arab dimana dalam metode

${ }^{4}$ Thoifuri, Menjadi Guru Inisiator. ( Semarang: Rasail Media Group). Hal. 55.

${ }^{5}$ Melvin L. Silberman, Active Learning 101 Cara Belajar Siswa Aktif. (Bandung ;Nusamedia, 2011) Hal. 1.

${ }^{6}$ Syaiful Bahri Djamarah, Aswan Zain, Strategi Belajar Mengajar. (Jakarta: PT Rineka Cipta). Hal. 100.

7 Wina Sanjaya, Strategi Pembelajaran Berorientasi Standar Proses Pendidikan. (Jakarta: Kencana Media Group 2007 ). Hal. 160. 
sosiodrama siswa harus menulis naskah dimana dalam menulis naskah siswa dilatih dalam kemahiran menulis ( Al-khitabah ), menghafal naskah berlatih membaca teks dalam kemahiran membaca ( Al- qira'ah ) ,selanjutnya mendramakan naskah yang telah ditulisnya, dalam kegiatan demonstrasi ini selain diasah mentalnya para siswa juga dilatih kemahirannya dalam berbicara ( Al-kalam ). Selain itu ketika mendramakan naskah para siswapun juga dilatih kemahirannya dalam hal mendengarkan ( Al-istima' ). Dan secara keseluruhan siswa yang menjadi audience juga dilatih menerjemahkan dan mendengarkan percakapan mereka. Sehingga siswa lebih aktif dalam pembelajarannya dan merasa senang dalam bahasa Arab karena dalam praktiknya Guru hanya menjadi pengarah dan pembimbing. Hal ini menjadikan suatu pelajaran efektif, efisien, dan menyenangkan dengan sebuah pertunjukan drama karena pembelajaran ini menjadi suatu hal yang menarik.

Pada kenyataanya pada pembelajaran bahasa Arab dikelas yang diperbanyak hanya teori saja dan kurang diperhatikannya untuk pengembangan kemampuan berbicara bahasa Arabnya sehingga siswa banyak yang kurang mampu dalam kemahiran berbicara ( Al-kalam ) bahasa arab dimana bahasa juga digunakan sebagai bahasa komunikasi dan perlu pembiasaan dalam mengucapkan kosa kata bahasa Arab. Untuk itu banyak siswa merasa bosan dan jenuh bahkan sebagian siswa ada yang tertidur dikelas ketika kegiatan pembelajaran berlangsung.

Berdasarkan uraian di atas peneliti merasa tertarik untuk Eksperimentaltasi dengan metode sosiodrama untuk mengembangkan atau meningkatkan kemahiran berbicara (Al-kalam) bahasa Arab di MTs Al Washliyah dan memilih judul“Penggunaan Metode Sosiodrama Terhadap Upaya Peningkatan Maharah Al-kalam Dalam Pembelajaran Bahasa Arab Siswa Kelas VIII MTs Al Washliyah Talun Kabupaten Cirebon.

\section{Metode Penelitian}

Penelitian dengan judul " "Penggunaan Metode Sosiodrama Serta Pengaruhnya Terhadap Peningkatan Siswa Dalam Kemahiran Berbicara (Study Eksperimental untuk kelas VIII siswa MTs Al Washliyah talun Cirebon)merupakan penelitian kuantitatif dan menggunakan jenis penelitian Quasi Eksperimentaltal Design. Desain yang digunakan dalam riset ini adalah Non Equivalent Control Group Design. Desain ini terdapat pretest dan posttest, sehingga pengaruh treatment dapat 
dihitung dengan cara membandingkan nilai kelas Eksperiment dan

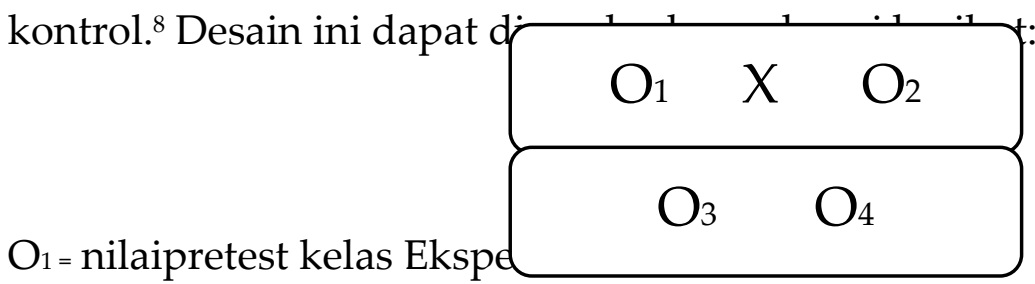

$\mathrm{O}_{2}=$ nilai posttest kelas Eksperimental

$\mathrm{O} 3=$ nilai pretest kelas control

$04=$ nilai posttest kelas kontrol

$X=$ perlakuan (treatment), dengan menggunakan metode sosiodrama.

Penelitian ini telah dilakukan dalam dua tahap yaitu pemberian tes awal (pretest) dan pemberian tes akhir (posttest). Pemberian tes awal dimana pada tahap ini tanpa diberikan perlakuan. Pemberian tes akhir diberikan perlakuan ditandai dengan X. Keduanya untuk mengetahui pengaruh kemampuan keterampilan berbicara (maharah kalam) sebelum dan sesudah menggunakan metode Sosiodrama terhadap kemampuan siswa dalam keterampilan berbicara. Penelitian ini dilaksanakan pada siswa kelas VIII MTs AlWashliyah Talun Cirebon.

Populasi adalah suatu wilayah generalisasi yang tersusun atas subyek maupun obyek yang memiliki kualitas dan ciri-ciri tertentu yang dipatenkan peneliti untuk dipahami dan dipelajari serta dibentuk sebuah kesimpulan. Populasi yang dipilih dalam penelitian ini yaitu seluruh siswa kelas VIII MTs AlWashliyah cirebon tahun ajaran 2018 / 2019. Jumlah seluruh siswa kelas VIII yaitu 38 siswa dari kelas A dan B.

Sampel adalah wakil atau sebagian populasi kecil yang akan diteliti. Pada penelitian ini, peneliti mengambil sampel dengan menggunakan teknik Cluster Sampling. Sampel untuk penelitian ini yaitu kelas B sebagai kelas Eksperimental dan kelas A sebagai kelas kontrol

Hatch dan Farhady, 1981 dalam Sugiyono mengatakan bahwa variabel merupakan suatu atribut yang dimiliki sebuah obyek atau seseorang yang memiliki sebuah variasi di antara satu orang dengan orang yang lain dan bisa dikatakan satu obyek dengan obyek yang lain.

Kerlinger 1973 dalam Sugiono menjelaskan bahwa variabel merupakan sifat maupun konstrak yang nantinya akan dipelajari.

${ }^{8}$ Lihat Sugiono, Metode Penelitian Pendidikan Pendekatan Kuantitatif dan RED (Bandung; PT Alpabeta, 2015). 
Contoh dari variabel ini misalnya tingkat aspirasi, pendidikan, status sosial, penghasilan, golongan gaji, produktivitas kerja, jenis kelamin dan lain sebagainya. Kerlinger juga menjelaskan bahwa suatu variabel dikatakan sebagai sifat yang akan diambil dari nilai yang berbeda. Maka dari itu variabel bisa dikatakan sesuatu yang bervariasi. Untuk pendapat selanjutnya yaitu dari Kidder, mengatakan bahwa suatu variabel adalah sebuah kualitas yang mana peneliti akan mempelajari dan menarik kesimpulan darinya.

Pada penelitian ini teknik pengumpulan data dapat diukur dengan adanya ketercapaian aspek dan penilaian yang digunakan sebagai data hasil dari penelitian dalam bentuk isntrument penelitian sebagai berikut:

Lembar tes yang digunakan pada penelitian ini terdapat dua jenis tes yaitu pretest dan posttest untuk mengetahui sejauh mana kemampuan siswa dalam keterampilan berbicra bahasa arab. Pada lembar tes terdapat tes lisan berupa Uraian yang digunakan siswa untuk menjawab tes lisan yang telah disediakan.

Teknik pengumpulan data yang dilakukan dalam penelitian ini akan diperoleh dari hasil pengumpulan data yang menggunakan teknik tes, dokumentasi dan observasi langsung. Teknik tes bertujuan untuk mengetahui sejauh mana kemampuan pemahaman siswa dalam kosakata bahasa arab. Tes dilaksanakan sebanyak dua kali, yaitu pretest dan posttest. Pretest digunakan untuk mengetahui kemampuan awal siswa terhadap pemahaman siswa dalam kosakata bahasa arab sebelum mendapatkan perlakuan. Sedangkan posttest digunakan untuk mengetahui pemahaman siswa setelah mendapatkan perlakuan. Teknik observasi dilakukan untuk mengamati pelaksanaan kegiatan pembelajaran bahasa arab dengan menggunakan metode Sosiodrama pada kelas Eksperimental secara langsung. Teknik observasi juga dilakukan untuk mengamati penelitian sebagai guru pelaksana pembelajaran ketika melaksanakan kegiatan pembelajaran, pengamatan dilakukan oleh guru.

Teknik analisis data ini diperoleh setelah semua data terkumpul dan akan dianalisis sehingga diperoleh hasil yang diperlukan dalam penelitian ini. Pada penelitian ini analisis data instrument menggunakan uji validitas dan uji realibilitas dan uji t test.Uji validitas adalah suatu ukuran yang menunjukan tingkat kevalidan dan kesahihan suatu instrument. Suatu instrument dikatakan valid apabila dapat 
mengungkap data dari variabel yang diteliti secara cepat. Validitas dalam penelitian ini diukur menggunakan program pengolahan data SPSS 21 dengan korelasi Product Moment. Kriteria item yang valid yaitu dengan melihat hasil probabilitas. Jika nilat thitung $>$ tabel maka item dinyatakan valid. Jika thitung $<$ tabel maka item dinyatakan tidak valid.

Uji realibilitas menunjuk pada suatu pengertian bahwa suatu instrument cukup dapat di percaya untuk digunakan sebagai alat pengumpul data karena instrumen sudah baik. Item yang valid akan dilakukan perhitungan realibilitas dengan menggunakan rumus Cronbach's Alpha dengan tujuan mencari koefesien realibilitasnya. Realibilitas dari skala ini diketahui dengan menggunakan program SPSS 21. Uji realibilitas dengan teknik Cronbach's Alpha yaitu dengan cara menentukan nilai varian tiap butir pertanyaan, menentukan nilai varian total dan menentukan realibilitas instrument.

$$
\mathrm{r}_{11}=\left(\frac{\mathrm{k}}{(\mathrm{k}-1)}\right)\left(1-\frac{\sum \sigma_{\mathrm{b}}^{2}}{\sigma_{\mathrm{t}}^{2}}\right)
$$

Kriteria uji realibilitas dalam rumus Cronbach's Alpha menggunakan batasan 0,6. Jika realibilitas < 0,6 maka kurang baik, jika realibilitas 0,7 dapat diterima dan jika realibilitas $>0,8$ maka baik.

Uji normalitas berguna untuk mengetahui setiap sampel yang akan digunakan berasal dari populasi yang terdistribusi normal atau tidak normal. Uji normalitas data pada penelitian ini dilakukan dengan menggunakan program pengolahan data SPSS 21 melalui uji normalitas Kolmogorov-Smirnov dengan kriteria jika signifikansi $>0,05$ maka data berdistribusi normal, dan jika signifikansi $<0,05$ maka data tidak berdistribusi normal.

Uji homogenitas dilakukan pada hasil data pretest dan posttest santri. Pada penelitian ini, uji homogenitas dilakukan dengan menggunakan program pengolahan data SPSS 21 melalui Levene. Kriteria pengujiannya adalah apabila nilai signifikansi atau probabilitas < 0,05 maka data tidak homogen, sedangkan jika nilai signifikansi atau nilai probabilitas $>0,05$ maka data homogen. ${ }^{9}$

Uji hipotesis pada penelitian ini menggunakan teknik t-test. Teknik ini merupakan teknik statistik yang dipergunakan untuk menguji

9 Suharsimi Arikunto, Prosedur Penelitian suatu Pendidikan Praktik. (Jakarta;Rineka Cipta,2013). Hal. 221. 
signifikansi perbedaan dua buah mean yang berasal dari dua buah mean distribusi (Winarsunu, 2015:75). Data yang diperoleh dalam penelitian ini berjenis rasio dan digunakan untuk mengetahui perbedaan nilai pretest dan posttest, perhitungannya menggunakan uji t-test. Uji t-test ini nantinya akan dijadikan pembanding antara kelas Eksperimental tanpa menggunakan perlakuan dan kelas Eksperimental menggunakan perlakuan. Adanya alasan menggunakan uji t-test ini yaitu karena tidak adanya keterkaitan antara sampel yang digunakan. Maksudnya yaitu perlakuan yang terdapat pada kelas Eksperimental melalui perlakuan pretest dan posttest. Uji t-test pada penelitian ini dilakukan dengan menggunakan program pengolahan data SPSS 21 dengan rumus Indipendent Samples T-Test.

\section{KETERAMPILAN BERBICARA (Maharat kalam)}

a. Definisi Kalam

Yang dimaksud dengan kalam adalah pengucapan bunyi- bunyi berbahasa arab dengan baik dan benar sesuai dengan bunyi-bunyi yang berasal dari mahkraj yang dikenal oleh para linguistic. ${ }^{10}$

b. Tujuan Pembelajaran Keterampilan Kalam

Tujuan pembelajaran kalam adalah sarana berinteraksi dengan orang lain dan memahami apa yang diinginkan penutur.

Pembelajaran ini dimulai setelah siswa mengetahui bunyi hurufhuruf bahasa Arab, mengetahui perbedaan antara bunyi huruf satu dengan huruf lainnya yang berbeda, $\mathrm{dsb} .{ }^{11}$

c. Prinsip-prinsip Pengajaran Keterampilan Kalam

Agar pembelajar kalam yang baik bagi non Arab, maka perlu diperhatikan hal-hal berikut:

1). Hendaknya guru memiliki kemampuan yang tinggi tentang keterampilan ini.

2). Memulai dengan suara-suara yang serupa antara dua bahasa ( bahasa pebelajar dan bahasa arab).

10 Abd. Wahab Rosyidi dan Mamlu'atul Nikmah, Memahami Konsep Dasar Pembelajaran Bahasa Arab. (Malang: UIN-Maliki Press, 2011). Hal. 89.

11 Abd. Wahab Rosyidi dan Mamlu'atul Nikmah, Memahami Konsep Dasar Pembelajaran Bahasa Arab. (Malang: UIN-Maliki Press, 2011). Hal. 90. 
3). Hendaknya pengarang dan pengajar memperhatikan tahapan dalam pengajaran kalam, seperti dengan lafadz-lafadz mudah yang terdiri dari satu kalimat, dua kalimat dan seterusnya.

4). Memulainya dengan kosa kata yang mudah.

5). Memfokuskan pada bagian keterampilan bagi keterampilan berbicara, yaitu:

a) Cara mengucapkan bunyi dari makhrajnya dengan baik dan benar.

b) Membedakan pengucapan harakat panjang dan pendek.

c) Mengunangkapkan ide-ide dengan cara yang benar dengan memperhatikan kaidah tata bahasa yang ada.

d) Melatih siswa bagaimana cara memulai dan mengakhiri pembicaraan dengan benar.

6) Memperbanyak latihan-latihan, seperti latihan membedakan pengucapan bunyi, latihan mengungkapkan ide-ide. ${ }^{12}$

d. Tahapan Pembelajaran Kalam

Tahapan-tahapan pembelajaran keterampilan berbicara ini dibagi menjadi tiga tingkatan, yaitu tahapan pada tingkat pemula, tingkat menengah dan tingkat lanjut. Adapaun penjelasannya adalah sebagai berikut:

1). Bagi tingkat mubtadi' (pemula)

a) Siswa diminta untuk belajar mengucapkan kata, menyusun kalimat dan mengungkapkan pikiran mereka secara sederhana.

b) Guru mengajukan pertanyaan-pertanyaan yang harus dijawab oleh siswa sehingga berakhir membentuk sebuah tema yang sempurna.

c) Guru mulai melatih bicara dengan member pertanyaanpertanyaan sederhana. ${ }^{13}$

d) Guru menyuruh siswa menjawab latihan-latihan syafahiyah dengan melafalkan percakapan, atau menjawab

12 Abd. Wahab Rosyidi dan Mamlu'atul Nikmah, Memahami Konsep Dasar Pembelajaran Bahasa Arab. (Malang: UIN-Maliki Press, 2011). Hal. 91.

13 Syaiful Mustofa, Strategi Pembelajaran Bahasa Arab Inovatif. (Malang: UINMaliki Press, 2011). Hal. 151. 
pertanyaan yang berhubungan dengan isi teks yang telah siswa baca.

2). Bagi tingkat mutawasit (menengah)

a) Belajar berbicara dengan bermain peran.

b) Berdiskusi dengan tema tertent.

c) Berbicara tentang peristiwa yang terjadi pada siswa

d) Bercerita tentang informasi yang telah didengar dari televisi, radio, atau lainya

3). Bagi tingkat mutaqaddim (tingkat atas)

a) Guru memilihkan tema untuk berlatih berbicara.

b) Tema yang dipilih hendaknya menarik, yang berhubungan dengan kehidupan siswa sehari-hari.

c) Tema harus jelas dan terbatas.

d) Siswa dipersilahkan untuk memilih satu tema atau lebih sampai akhirnya siswa bebas memilih tema yang dibicarakan tentang apa yang mereka ketahui. ${ }^{14}$

Didalam proses pembelajaran keterampilan berbicara, seorang pengajar juga harus melakukan pembetulan secara langsung pada aspek kesalahan siswa, serta ada aspek penilaian diakhir pertemuan tersebut.

1. Pembetulan aspek berbicara

Dalam berbagai latihan berbicara, terutama percakapan, bercerita, diskusi dan seterusnya, pengajar seringkali menemukan kesalahan dan kekurangan siswa, baik pada aspek kebahasaan maupun nonkebahasaan. Guru seringkali merasa risih dan tidak sabar untuk segera membetulkannya. Hal ini bisa difahami karena boleh jadi pengajar merasa berkewajiban untuk tidak membiarkan siswa berkelanjutan dalam kesalahan. ${ }^{15}$

2. Aspek Penilaian

Adapun aspek-aspek yang dinilai pada akhir pertemuan dalam kegiatan berbicara, sebagaimana disarankan oleh para ahli adalah sebagai berikut:

a. Aspek kebahasaan

14 Syaiful Mustofa, Strategi Pembelajaran Bahasa Arab Inovatif. (Malang: UINMaliki Press, 2011). Hal. 152.

15 Syaiful Mustofa, Strategi Pembelajaran Bahasa Arab Inovatif. (Malang: UINMaliki Press, 2011). Hal. 153. 
1) Pengucapan (makhraj)

2) Ketepatan bacaan (mad, syiddah)

3) Penempatan tekanan (intonasi)

4) Nada dan irama

5) Pilihan kata

6) Kelincahan

7) Sistematika pembicaraan

8) Kerjasama

Skala penilaian ini dapat dipergunakan untuk penilaian individual maupun kelompok. ${ }^{16}$

\section{Metode Pembelajaran Bahasa Arab}

Metode adalah cara mengajar yang digunakan oleh pengajar dalam sebuah proses pembelajaran bahasa agar tercipta tujuan yang ingin dicapai. Ketepatan seorang pengajar dalam memilih sebuah metode akan sangat menentukan keberhasilan pembelajaran tersebut. ${ }^{17}$

\section{Metode Sosiodrama}

Belajar sambil bermain dipilih oleh peneliti karena peneliti beranggapan bahwa seorang anak tidak bisa jauh dari bermain.Bermain adalah alat pelepas emosi (Freud, 1958), pengembangan diri dalam bersosial (Erikson, 1963), ekspresi leluasa tanpa tekanan batin. ${ }^{18}$

Metode sosiodrama dan role playing dapat dikatakan sama artinya, dan dalam pemakaiannya sering disilihgantikan. Sosiodrama pada dasarnya mendramatisasikan tingkah laku dalam hubungannya dengan masalah sosial.

Tujuan yang diaharapkan dengan penggunaan metode sosiodrama antara lain:

a. Agar siswa dapat menghayati dan menghargai orang lain.

b. Dapat belajar bagaimana membagi tanggung jawab.

c. Dapat belajar mengambil keputusan dalam situasi kelompok secara spontan.

16 Syaiful Mustofa, Strategi Pembelajaran Bahasa Arab Inovatif. (Malang: UINMaliki Press, 2011). Hal. 155.

17 Syaiful Mustofa, Strategi Pembelajaran Bahasa Arab Inovatif. (Malang: UINMaliki Press, 2011). Hal. 13.

${ }^{18}$ Slamet Suyanto, Dasar-dasar Pendidikan Usia Dini. (Yogyakarta: Hikayat, 2005). Hal. 116. 
d. Merangsang kelas untuk berpikir dan memecahkan masalah. Petunjuk guna menggunakan metode sosiodrama adalah:

a. Tetapkan dahulu masalah- masalah sosial yang menarik perhatian siswa dikelas.

b. Ceritakan kepada kelas (siswa) mengenai isi dari masalah-masalah dalam konteks cerita tersebut.

c. Tetapkan siswa yang dapat atau bersedia untuk memainkan peranannya didepan kelas.

d. Jelaskan kepada pendengar mengenai peranan mereka pada waktu sosiodrama sedang berlangsung.

e. Beri kesempatan kepada para pelaku untuk berunding beberapa menit sebelum mereka memainkan peranannya.

f. Akhirisosiodrama pada waktu situasi pembicaraan mencapai ketegangan.

g. Akhirisosiodrama dengan diskusi kelas untuk

bersama-sama memecahkan masalah persoalan yang ada pada sosiodrama tersebut.

h. Jangan lupa menilai hasil sosiodrama tersebut sebagai bahan pertimbangan lebih lanjut. ${ }^{19}$

Bila sosiodrama baru diterapkan dalam pengajaran, maka hendaknya guru terlebih dahulu menerangkan teknik pelaksanaanya, danmenentukan diantara siswa yang tepat untuk memerankan lakon tertentu, yang secara sederhana dimainkan didepan kelas. Setelah pementasan selesai, yang dilakukan guru adalah mengevaluasi hasil sosiodrama yang telah diperankan dengan cara mendiskusikannya bersama-sama dengan siswa, serta memecahkan masalah-masalah yang ada pada sosiodrama.

Dalam pelaksanaaanya, selain naskah cerita yang didramakan diberikan oleh guru, siswa diberi kesempatan untuk menyusun naskah ceritanya sendiri.Hal ini bertujuan agar siswa mampu mengembangkan kemampuan siswa untuk berpikir kritis dan kreatif, sehingga siswa mendapatkan pengalaman langsung dan berkesan dengan kuat serta tahan lama dalam ingatan siswa.Disamping merupakan pengalaman yang menyenangkan yang sulit untuk dilupakan.

19 Syaiful Bahri Djamarah, Aswan Zain, Strategi Belajar Mengajar. (Jakarta: PT Rineka Cipta). Hal. 100. 


\section{Pengaruh Penggunaan Metode Sosiodrama terhadap Peningkatan Kemampuan Keterampilan Berbicara}

Pada tes ini dimulai dengan memberikan pretest di kelas kontrol. Waktu yang diberikan kepada siswa sekitar 45 menit. Setelah dilaksanakan pretest, peneliti melaksanakan pembelajaran bahasa arab tanpa menggunakan metode sosiodrama. Setelah pembelajaran selesai dan untuk mengetahui kemampuan pemahaman siswa peneliti melakukan posttest untuk mengetahui perbedaan kemampuan pemahaman siswa sebelum dan sesudah pembelajaran tanpa menggunakan media gambar dan metode index card match. Adapun hasilnya sebagai berikut:

Statistics

\begin{tabular}{|ll|r|r|}
\hline & & Pre testKontrol & Post testkontrol \\
\hline N & Valid & 19 & 19 \\
Mean & Missing & 0 & 0 \\
Median & & 48.16 & 72.42 \\
Mode & 50.00 & 72.00 \\
Minimum & $40^{\mathrm{a}}$ & 68 \\
Maximum & 40 & 68 \\
Sum & 55 & 80 \\
\hline
\end{tabular}

Diketahui hasil perhitingan SPSS 21 dari nilai pretest di kelas kontrol yaitudengannilaiminimum40,maksimum55, median 50.00denganrata-rata48,16.Sedangkan dari nilai posttestdi kelaskontrolyaitudengannilaiminimum68, maksimum80, median 72.00denganrata-rata72,42.

Pada tes ini dimulai dengan memberikan pretest di kelas Eksperimental. Waktu yang diberikan kepada siswa sekitar 45 menit. Setelah dilaksanakan pretest, peneliti melaksanakan pembelajaran kosakata bahasa arab dengan menggunakan media gambar dan metode index card match. Setelah pembelajaran selesai dan untuk mengetahui kemampuan pemahaman siswa peneliti melakukan posttest untuk mengetahui perbedaan kemampuan pemahaman siswa sebelum dan 
sesudah pembelajaran dengan menggunakan media gambar dan metode index card match. Adapun hasilnya sebagai berikut:

\section{Statistics}

\begin{tabular}{|c|c|c|c|}
\hline & & Pre testEksperimental & Post testEksperimental \\
\hline \multirow{2}{*}{$\mathrm{N}$} & Valid & 19 & 19 \\
\hline & Missing & 0 & 0 \\
\hline \multicolumn{2}{|c|}{ Mean } & 48.53 & 82.42 \\
\hline \multicolumn{2}{|c|}{ Median } & 48.00 & 82.00 \\
\hline \multicolumn{2}{|c|}{ Mode } & 50 & 80 \\
\hline \multicolumn{2}{|c|}{ Minimum } & 40 & 75 \\
\hline \multicolumn{2}{|c|}{ Maximum } & 60 & 92 \\
\hline \multicolumn{2}{|c|}{ Sum } & 922 & 1566 \\
\hline
\end{tabular}

Diketahui hasil perhitingan SPSS 21 dari nilai pretest di kelas ekspermen yaitudengannilaiminimum40,maksimum60, median 48.00denganrata-rata48,53.Sedangkan dari nilai posttestdi kelaskontrolyaitudengannilaiminimum75, maksimum92, median 82.00denganrata-rata82,42.

\section{Uji Normalitas}

Uji normalitas berguna untuk mengetahui setiap sampel yang akan digunakan berasal dari populasi yang terdistribusi normal atau tidak normal. Uji normalitas data pada penelitian ini dilakukan dengan menggunakan program pengolahan data SPSS 21 melalui uji normalitas Kolmogorov-Smirnov dengan kriteria jika signifikansi $>0,05$ maka data berdistribusi normal, dan jika signifikansi $<0,05$ maka data berdistribusi tidak normal. Adapun hasil uji normalitas pada penelitian ini sebagai berikut:

Tests of Normality

\begin{tabular}{|r|r|r|r|r|r|r|r|}
\hline \multirow{2}{*}{} & \multirow{2}{*}{ kelas } & \multicolumn{3}{|c|}{ Kolmogorov-Smirnov } & \multicolumn{3}{|c|}{ Shapiro-Wilk } \\
\cline { 3 - 8 } & & Statistic & \multicolumn{1}{c|}{ Df } & \multicolumn{1}{c|}{ Sig. } & \multicolumn{1}{c|}{ Statistic } & \multicolumn{1}{c|}{$\mathrm{df}$} & \multicolumn{1}{c|}{ Sig. } \\
\hline \multirow{2}{*}{ Belajar } & pretest Eksperimental & .120 & 19 & $.200^{*}$ & .966 & 19 & .685 \\
& postestEksperimental & .189 & 19 & .073 & .953 & 19 & .448
\end{tabular}




\begin{tabular}{|l|l|l|l|l|l|l|}
\hline pretest kontrol & .180 & 19 & .106 & .889 & 19 & .031 \\
postestkontrol & .194 & 19 & .057 & .882 & 19 & .023 \\
\hline
\end{tabular}

Dari tabel di atas diketahui bahwa uji normalitas di kelas control pretest-posttest dan kelas ekperimen pretest-postest sebesar $(0,57>0,05)$ dan $(0,73>0,05)$. Hal ini dapat diketahui bahwa uji nomalitas berdistribusi normal.

\section{Uji Homogenitas}

Uji homogenitas dilakukan pada hasil data pretest dan posttest santri. Pada penelitian ini, uji homogenitas dilakukan dengan menggunakan program pengolahan data SPSS 21 melalui Levene. Kriteria pengujiannya adalah apabila nilai signifikansi atau probabilitas $<0,05$ maka data tidak homogen, sedangkan jika nilai signifikansi atau nilai probabilitas $>0,05$ maka data homogen.

Test of Homogeneity of Variances

\begin{tabular}{|c|c|c|c|}
\hline Levene Statistic & df1 & df2 & Sig. \\
\hline .008 & 1 & 36 & .931 \\
\hline
\end{tabular}

ANOVA

Hasilbelajarkelas

\begin{tabular}{|l|r|r|r|r||}
\hline & Sum of Squares & Df & Mean Square & \multicolumn{1}{||}{ F } \\
& & & & \\
\hline Between Groups & 950.000 & 1 & 950.000 & 53.836 \\
Within Groups & 635.263 & 36 & 17.646 & \\
\hline
\end{tabular}


Dari tabel diatas diketahui bahwa uji Homogenitas dikelas kontrol dan kelas Eksperimental sebesar 0,931>0,05. Hal ini berarti dapat kita ketahui data berdistribusi Homogen.

\section{Uji hipotesis}

Uji Hipotesis pada penelitian ini menggunakan teknik t-test. Teknik ini merupakan teknik statistik yang dipergunakan untuk menguji signifikansi perbedaan dua buah mean yang berasal dari dua buah distribusi.

Paired Samples Test

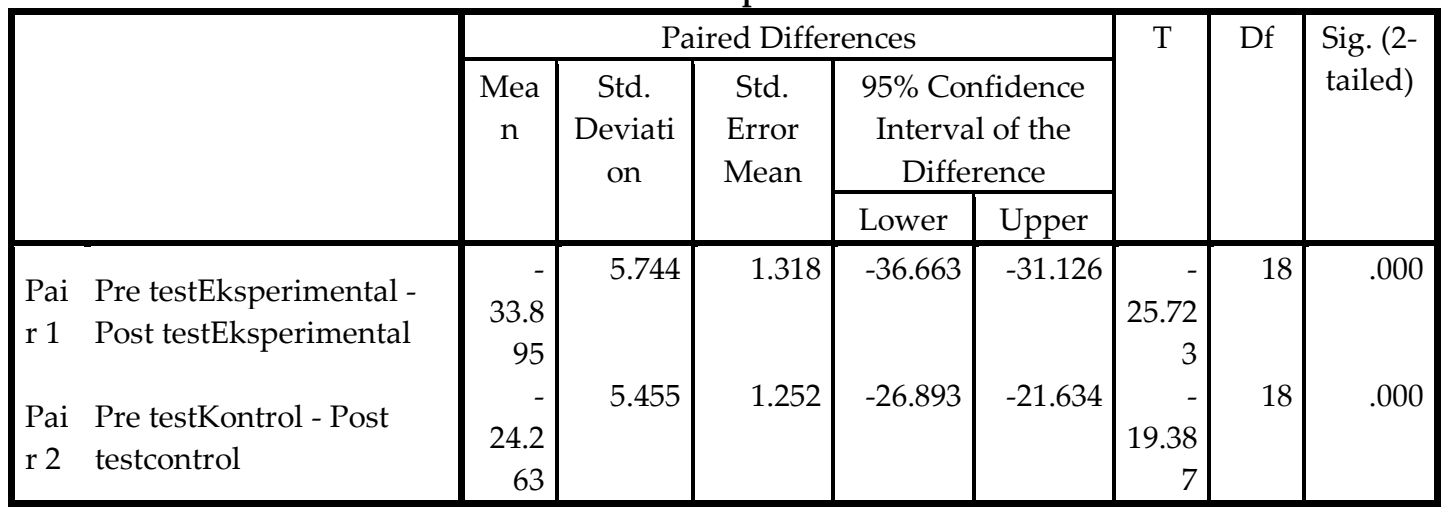

\section{Kesimpulan}

kemampuan siswa terhadap keterampilan berbicara tanpa menggunakan metode sosiodrama di kelaskontrol pada nilai pretestyaitudengannilaiminimum40,maksimum55, median 50.00denganrata-rata48,16.Sedangkan dari nilai posttestdi kelaskontrolyaitudengannilaiminimum68, maksimum80, median 72.00denganrata-rata72,46. Dan kemampuansiswaterhadap keterampilan berbicara denganmenggunakanmetode sosiodramadi kelasEksperimental pada nilai pretestyaitudengan nilaiminimum40,maksimum60, median 48.00denganratarata48,53.Sedangkan dari nilai posttestdi kelasEksperimentalyaitudengannilaiminimum75, maksimum92, median 82.00denganrata-rata82,42. Hal ini berarti terdapat peningkatan yang besar pada hasil pretest dan posttest. 
Terdapat pengaruh yang signifikan dari pemberian perlakuan terhadap kemampuansiswaterhadap keterampilan bebicara (maharat kalam) (maharat kalam) dengan menggunakanmedia gambar dan metode index card march. Hal ini dibuktikan dari perhitungan T-Test dengan menggunakan analisis SPSS 21. Hasil yang diperoleh dari perhitungan tersebut adalah nilai Sig.( 2 tailed) sebesar 0,000 . Hasil sig. (2 tailed) sebesar 0,000 yang berarti bahwa nilai ini lebih kecil dari 0,05 dimana dapat disimpulkan bahwa Ha diterima dan Ho ditolak.

\section{Daftar Pustaka}

Arikunto, Suharsimi. 2015. Prosedur Penelitian. Jakarta: PT Rineka Cipta.

Djamarah, Syaiful Bahri \& Zain,Aswan. Strategi Belajar Mengajar. Jakarta: PT Rineka Cipta.

Mustofa, Syaiful. 2011. Strategi Pembelajaran Bahasa Arab Inovatif. Malang: UIN-Maliki Press.

Rosyidi, Abd. Wahab \& Mamlu'atul Nikmah. 2011. Memahami Konsep Dasar Pembelajaran Bahasa Arab. Malang: UIN-Maliki Press.

Sanjaya,Wina. 2007. Strategi Pembelajaran Berorientasi Standar Proses Pendidikan. Jakarta: Kencana Media Group.

Silberman,Melvin L. 2011. Active Learning 101 Cara Belajar Siswa Aktif. Bandung: Nusamedia.

Sugiyono. 2011. Metode Penelitian Kuantitatif Kualitatif Dan RED. Bandung: Alfabeta.

Suyanto, Slamet. 2005. Dasar-dasar Pendidikan Usia Dini. Yogyakarta: Hikayat.

Tarigan 1981. Berbicara sebagai suatu Keterampilan Berbahasa. Bandung; Angkasa.

Tarigan. 2008. Menulis sebagai suatu Keterampilan Berbahasa. Bandung: Angkasa.

Thoifuri. Menjadi Guru Inisiator. Semarang: Rasail Media Group.

Trianto. 2007. Model Pembelajaran Terpadu dalam Teori dan Praktek. Jakarta: Prestasi Pustaka. 